Original Research Paper

\title{
Pelatihan Penyusunan Instrumen Keterampilan Berpikir Tingkat Tinggi Bagi Pendidik Mata Pelajaran IPA SMP Di Kota Mataram
}

\author{
Jamaluddin $^{1 *}$, Yayuk Andayani ${ }^{2}$, Agus Abhi Purwoko \\ ${ }^{1}$ Program Studi Pendidikan Biologi,Universitas Mataram, Indonesia \\ ${ }^{2}$ Program Studi Pendidikan Kimia,Universitas Mataram, Indonesia
}

*Corresponding Author:

Jamaluddin, Program Studi

Pendidikan Biologi,

Universitas Mataram,

Indonesia.

Email:

jamaluddin.fkip@unram.ac.id
Abstrak: Tujuan dari kegiatan pengabdian pada masyarakat ini adalah untuk: 1) meningkatkan kompetensi pedagogik pendidik tentang prosedur penyusunan instrument berpikir tingkat tinggi peserta didik pada pembelajaran IPA SMP; 2) memberikan pelatihan kepada para pendidik IPA dalam mengembangkan instrument keterampilan berpikir tingkat tinggi peserta didik melalui pembelajaran IPA SMP di Kota Mataram. Melalui kegiatan pengabdian pada masyarakat dalam bentuk presentasi, diskusi, dan pelatihan kepada para pendidik IPA diharapkan dapat: 1) memberikan manfaat secara praktis bagi upaya peningkatan pembelajaran IPA yang berorientasi peningkatan keterampilan berpikir tingkat tinggi peserta didi; 2) hasil kegiatan pengabdian ini berupa deskripsi prosedur tentang pengembangan instrument keterampilan berpikir tingkat tinggi peserta didik melalui pembelajaran IPA yang diharapkan dapat dapat mengembangkan kompetensi pedagogik pendidik IPA yang terlibat dalam kegiatan pengebdian ini; 3) instrumen yang dikembangkan melalui kegiatan ini secara praktis dapat digunakan oleh para pendidik merencanakan dan melaksanakan penilaian hasil pembelajaran IPA yang berorientasi pada upaya peningkatan keterampilan berpikir tingkat tinggi peserta didik. Kegiatan pengabdian pada masyarakat ini dilaksanakan dengan langkah-langkah sebagai berikut: 1) memberikan pemahaman kepada pendidik IPA tentang pentingnya peningkatan keterampilan berpikir tingkat tinggi peserta didik dalam kaitannya dengan era komunikasi dan informasi dewasa ini; 2) memberikan pelatihan kepada pendidik IPA tentang prosedur penyusunan instrument keterampilan berpikr tingkat tinggi peserta didik. Metode yang digunakan dalam pelaksanaan kegiatan pengabdian pada masyarakat ini adalah metode observasi, diskusi informasi, pelatihan menyusun instrument keterampilan berpikir tingkat tinggi peserta didik. Hasil yang diperoleh melalui kegiatan pengabdian pada masyarakat ini adalah Para pendidik IPA SMP di Kota Mataram yang terlibat dalam kegiatan PPM ini telah memiliki pemahaman dan keterampilan dalam penyusunan instrument untuk mengukur keterampilan berpikir tingkat tinggi peserta didik melalui pembelajaran IPA SMP di Kota Mataram.

Kata Kunci: Berpikir Tingkat Tinggi, Kompetensi pedagogik, Instrumen Keterampilan Berpikir

\section{Pendahuluan}

Kurikulum 2013 yang telah diberlakukan untuk semua jenjang pendidikan telah dikembangkan dengan berbagai penyempurnaan. Penyempurnaan antara lain dilakukan pada standar isi yaitu mengurangi materi yang tidak relevan serta pendalaman dan perluasan materi yang relevan bagi peserta didik serta diperkaya dengan kebutuhan peserta didik untuk berpikir kritis dan analitis sesuai dengan standar internasional. Penyempurnaan lainnya juga dilakukan pada standar penilaian, dengan mengadaptasi secara bertahap model-model penilaian standar internasional. Penilaian hasil belajar diharapkan dapat membantu peserta didik untuk meningkatkan 
kemampuan berpikir tingkat tinggi (Higher Order Thinking Skills/HOTS), karena berpikir tingkat tinggi dapat mendorong peserta didik untuk berpikir secara luas dan mendalam tentang materi pelajaran (Kemendikbud, 2017).

Peningkatan kemampuan berpikir tingkat tinggi peserta didik dapat dilakukan melalui perubahan sistem dalam pembelajaran dan penilaian. Penilaian yang dikembangkan oleh pendidik diharapkan dapat mendorong peningkatan kemampuan berpikir tingkat tinggi, meningkatkan kreativitas, dan membangun kemandirian peserta didik untuk menyelesaikan masalah. Oleh karena itu pendidik perlu memiliki kemampuan dalam penyususnan soal-soal yang berorientasi pada pengembangan kemampuan berpikir tingkat tinggi peserta.

Kemampuan berpikir tingkat tinggi termasuk kemampuan untuk memecahkan masalah (problem solving), kemampuan berpikir kritis (critical thinking), berpikir kreatif (creative thinking), kemampuan berargumen (reasoning), dan kemampuan mengambil keputusan (decision making). Kemampuan berpikir tingkat tinggi merupakan salah satu kompetensi penting dalam dunia modern, sehingga wajib dimiliki oleh setiap peserta didik (Kemendikbud 2017).

Pembelajaran IPA memegang peranan penting dalam mengembangkan pengetahuan, kemampuan berpikir, dan sikap peserta didik. Melalui pembelajaran IPA peserta didik dapat mengenal, menyikapi dan mengapresiasi ilmu pengetahuan dan teknologi, serta menanamkan kebiasaan berpikir dan berprilaku ilmiah yang kritis, kreatif dan mandiri (BNSP, 2006b). Melalui pembelajaran IPA tidak hanya menekankan pada pemahaman konsep semata, tetapi juga penting bagi pendidik untuk mengembangkan kemampuan berpikir tingkat tinggi peserta didik, karena kemampuan berpikir tingkat tinggi adalah suatu kecakapan hidup yang sangat dibutuhkan peserta didik untuk dapat berkompetisi di era sistem komunikasi dan informasi saat ini dan dimasa yang akan datang (Jamaluddin dkk, 2017).

Peraturan Menteri Pendidikan dan Kebudayaan nomor 20 tahun 2016 tentang standar kompetensi lulusan pendidikan dasar dan menengah menyatakan bahwa lulusan SMP diharapkan memiliki kemampuan berpikir dan bertindak kreatif, produktif, kritis, mandiri, kolaboratif, dan komunikatif melalui pendekatan ilmiah sesuai dengan yang dipelajari di satuan pendidikan dan sumber lain secara mandiri (Kemendikbud, 2016).

Melalui pembelajaran IPA di SMP, pendidik perlu menyadari bahwa IPA berhubungan dengan cara mencari tahu tentang alam secara sistematis, sehingga IPA bukan hanya kumpulan pengetahuan yang berupa fakta-fakta, konsep-konsep, atau prinsip-prinsip saja tetapi juga merupakan proses penemuan (Sulistyorini, 2007). Unuk itulah sudah seharusnya pembelajaran IPA dilaksanakan untuk mengembangkan kemampuan berpikir sebagai suatu proses penting agar mereka memiliki kecakapan hidup dimasa depannya.

Pembelajaran IPA tidak semata-semata berorientasi pada pemahaman tentang produkproduk IPA dalam berupa konsep-konsep, prinsipprinsip, teori-teori dan hukum-hukum alam, karena hakekat pembelajaran IPA sebenarnya adalah agar peserta didik menguasai produk IPA melalui suatu proses ilmiah yang disebut dengan metode ilmiah. Melalui pembelajaran IPA pendidik dapat mengembangkan sikap ilmiah peserta didik. Kemampuan berpikir tingkat tinggi merupakan kemampuan yang sangat dibutuhkan oleh setiap warga negara untuk dapat mampu berkompetensi dalam persaingan global dimasa kini dan masa yang akan datang. Kemampuan berpikir dimaksud diantaranya adalah kemampuan berpikir kritis, kreatif, metakognisi, dan pemecahan masalah.

Mata pelajaran IPA di SMP termasuk dalam kelompok mata pelajaran ilmu pengetahuan dan teknologi. Ruang lingkup kajiannya adalah agar peserta didik mengenal, menyikapi dan mengapresiasi ilmu pengetahuan dan teknologi, serta menanamkan kebiasaan berpikir dan berprilaku ilmiah yang kritis, kreatif dan mandiri (BSNP, 2006a). Melalui mata pelajaran IPA diharapkan peserta didik dapat tumbuh menjadi SDM yang responsif terhadap perkembangan IPTEK dan terampil dalam berpikir. Untuk mencapai maksud tersebut, proses pembelajaran IPA perlu diarahkan pada pembelajaran pengembangan berpikir tingkat tinggi (Jamaluddin dkk, 2017).

Dari paparan di atas menunjukkan bahwa peserta didik sebagai SDM Indonesia masa depan adalah aset terbesar dari negara yang harus dikelola, dibimbing dan dilatih untuk menjadi manusia unggul melalui proses pembelajaran yang relevan dengan tuntutan masyarakat dan 
perkembangan IPTEK di era informasi ini. Untuk itulah pembelajaran yang berorientasi pemahaman IPTEK dan kemampuan berpikir tingkat tinggi menjadi sangat relevan untuk dilaksanakan pada semua jenjang pendidikan. Hal ini dimaksudkan agar lulusan dapat beradaptasi di masa depannya, dan mereka dapat tampil sebagai subyek atau pelopor dalam pengembangan IPTEK yang berbasis informasi. Untuk mencapai maksud tersebut diperlukan SDM Indonesia yang memiliki kemampuan berpikir tingkat tinggi yang memiliki keunggulan kompetitif dalam persaingan masyarakat global (Jamaluddin, 2009).

Dalam melaksanakan pembelajaran hendaknya pendidik menyadari bahwa perkembangan IPA dan teknologi saat ini maupun di masa depan sangat membutuhkan SDM yang memiliki keunggulan dalam berpikir. Untuk mengembangkan SDM dimaksud perlu dilakukan melalui pembelajaran pengembangan berpikir secara sengaja bahkan terprogram selama pembelajaran. Corebima dan Al Idrus (2006) menerangkan bahwa pembelajaran yang secara sengaja dan terprogram memberdayakan kemampuan berpikir diyakini akan memungkinkan para peserta didik menjadi anggota masyarakat dunia masa depan, bahkan berpeluang besar para peserta didik menjadi pelaku pengembangan sains dan teknologi masa depan. Pembelajaran pengembangan kemampuan berpikir perlu dilaksanakan secara terencana di setiap jenjang pendidikan agar peserta didik tumbuh dan berkembang menjadi pemikir-pemikir logis, kritis dan kreatif.

Pengembangan kemampuan berpikir peserta didik bertujuan agar mereka dapat tumbuh menjadi Sumber Daya Manusia (SDM) yang mampu bertahan di tengah gelombang persaingan global di masa kini dan masa depannya yang semakin rumit dan demikian kompleksnya dalam berbagai aspek kehidupan masyarakat Perkembangan dunia di era globalisasi membutuhkan SDM yang mampu berkompetisi dan sekaligus bekerja sama dengan SDM dari negara lain. Bangsa yang tidak siap berkompetisi akan tertinggal dalam segala bidang terutama bidang ilmu pengetahuan dan teknologi (IPTEK). Agar bangsa Indonesia mampu bersaing dengan bangsa lain sangat ditentukan oleh keunggulan SDM yang dihasilkan melalui proses pendidikan (Jamaluddin, 2009).
Hasil observasi menunjukkan bahwa para pendidik mengalami kesulitan dalam hal mengembangkan pembelajaran berorientasi pada pengembangan kemampuan berpikir tingkat tinggi peserta didik, demikian pula dengan pengembangan instrumen penilaian untuk mengukur kemampuan berpikir tingkat tinggi peserta didik melalui pembelajaran IPA di SMP. Hal ini dapat diketahui dari rencana pembelajaran dan instrumen evaluasi yang disusun pendidik IPA yang menunjukkan bahwa pembelajaran pengembangan berpikir tingkat tinggi termasuk pengemabangan instrumen kemampuan berpikir tingkat tinggi untuk peserta didik belum dilakukan dengan sengaja dan terencana. Alat evaluasi yang dikembangkan hanya berorientasi pada alat penilaian yang mengkur penguasaan konsep IPA. Untuk itulah melalui kegiatan pengabdian ini dipandang perlu untuk melatih para pendidik IPA dalam mengembangkan instrumen penilaian untuk mengukur kemampuan berpikir tingkat tinggi peserta didik melalui pembelajaran IPA di SMP.

Dari hasil observasi pembelajaran IPA dan hasil wawancara diketahui bahwa para pendidik mata pelajaran IPA belum memahami dengan benar tentang prosedur penyusunan instrument kemampuan tingkat tinggi peserta didik melalui pembelajaran IPA di SMP. Untuk lebih terarahnya kegiatan ini rumusan masalah dari pengabdian pada masyarakat ini adalah:

1. Bagaimana meningkatkan pemahaman pendidik tentang prosedur penyusunan instrument kemampuan berpikir tingkat tinggi peserta didik melalui pelajaran IPA di SMP?

2. Bagaimana contoh instrument untuk mengukur kemampuan berpikir tingkat tinggi peserta didik yang dapat diterapkan melalui pembelajaran IPA di SMP?

Tujuan dari kegiatan pengabdian pada masyarakat ini adalah untuk 1)Meningkatkan kompetensi pedagogik pendidik tentang prosedur penyusunan instrument berpikir tingkat tinggi peserta didik pada pembelajaran IPA SMP; 2) memberikan pelatihan kepada para pendidik IPA dalam mengembangkan instrument kemampuan berpikir tingkat tinggi peserta didik melalui pembelajaran IPA SMP di Kota Mataram. Melalui kegiatan pengabdian pada masyarakat dalam bentuk presentasi, diskusi, dan pelatihan kepada para pendidik IPA diharapkan dapat: 1) memberikan manfaat secara praktis bagi upaya peningkatan 
pembelajaran IPA yang berorientasi peningkatan kemampuan berpikir tingkat tinggi peserta didik; 2) hasil kegiatan pengabdian ini berupa deskripsi prosedur tentang pengembangan instrument kemampuan berpikir peserta didik melalui pembelajaran yang diharapkan dapat dapat mengembangkan kompetensi pedagogik pendidik IPA, terutama yang terlibat dalam kegiatan pengebdian ini. 3) instrumen yang dikembangkan melalui kegiatan ini secara praktis dapat digunakan oleh para pendidik merencanakan dan melaksanakan pembelajaran IPA yang berorientasi pada upaya peningkatan kemampuan berpikir tingkat tinggi peserta didik.

Permasalahan yang dialami oleh Pendidik IPASMP di Kota Mataram adalah mereka belum terlatih untuk mengembangkan atau menyusun soal-soal untuk mengukur kemampuan berpikir tingkat tinggi. Soal-soal yang biasa mereka susun untuk keperluan ulangan formatif atau ulangan sumatif adalah soalsoal yang mengukur kemampuan berpikir tingkat rendah dan sedang. Soal-soal tersebut dapat dilihat pada rencana pelaksanaan pembelajaran (RPP) yang mereka susun. Soal-soal yang disusun tersebut lebih banyak membutuhkan jawaban yang bersifat hafalan. Dengan demikian peserta didik menjadi terbiasa belajar untuk menghafl materi pelajaran daripada berlatih berpikir tingkat tinggi.

Agar pendidik IPA SMP di Kota Mataram dapat menyusun instrument kemampuan berpikir tingkat tinggi peserta didiknya, perlu dilatih melalui kegiatan pengabdian pada masyarakat ini yang telah dilaksanakan dengan langkah-langkah sebagai berikut: 1) Memberikan pemahaman kepada pendidik IPA tentang pentingnya peningkatan kemampuan berpikir tingkat tinggi peserta didik dalam kaitannya dengan era komunikasi informasi dewasa ini; 2) memberikan pelatihan kepada pendidik IPA tentang prosedur penyusunan instrument kemampuan berpikr tingkat tinggi peserta didik; 3) Menunjukkah contoh instrumen kemampuan berpikir tingkat tinggi dalam hal ini diberikan contoh instrumen kemampuan berpikir kritis.

Kegiatan PPM ini terkait dengan upaya peningkatan kompetensi paedagogik pendidikpendidik IPA dalam mengidentifikasi kemampuan berpikir tingkat tinggi peserta didiknya. Hasil identifikasi tersebut dapat digunakan sebagai acuan dalam merancang dan melaksanakan pembelajaran
IPA yang berpotensi untuk meningkatkan kemampuan berpikir tingkat tinggi peserta didik. Peningkatan kemampuan dimasud merupakan hal yang penting sebagai suatu upaya pengembangan SDM masa depan yang memiliki kemampuan berpikir tingkat tinggi dalam menghadapi tantangan kehidupan di era komunikasi dan informasi dewasa ini. Untuk itulah maka para pendidik harus memiliki kemampuan yang memadai dalah mengembangkan instrument kemampuan berpikir tingkat tinggi. Instrumen dimaksud nanti akan gunakan untuk melatih kemampuan berpikir tingkattinggi peserta didik.

Melalui kegiatan PPM telah dicapai target luaran dalam bentuk upaya pemecahan masalah kurangnya pemahaman dan keterampilan guru dalam mengembangan soal-soal berpikir tingkat tinggi pendidik. Melalui kegiatan diskusi dalan pelatihan yang telah dikuti oleh 25 orang pendidik IPA maka kesulitan yang dialami oleh mereka dapat teratasi. Dengan demikian para pendidik IPA SMP yang telah terlibat secara aktif dalam kegiatan PPM telah memiliki pemahaman dan keterampil dalam mengembangkan instrument kemampuan berpikir kritis sebagai salah dari kemampuan berpikir tingkat tinggi.

\section{Metode Pelaksanaan}

Metode yang digunakan dalam pelaksanaan kegiatan pengabdian pada masyarakat ini adalah metode diskusi informasi, latihan dan penugasan. Kemudian dilanjutkan dengan kegiatan pendampingan dalam mengembangkan instrument kemampuan berpikir tingkat tinggi dalam bentuk tes kemampuan berpikir kritis peserta didik SMP. Berikut adalah uraian tentang masing-masing metode yang telah digunakan dalam pelaksanaan kegiatan pengabdian pada masyarakat ini:

1. Metode diskusi informasi, digunakan untuk menjelaskan kepada peserta pengabdian tentang pengertian, konsep dan prosedur pengembangan instrument kemampuan berpikir berpikir kritis melalui pembelajaran IPA di SMP. Penjelasan diamksud berisi tentang:
a. Teknik analisis Kompetensi Dasar manjadi sejumlah Indikator yang berpotensi untuk dikembangkan 
menjadi soal kemampuan berpikir tingkat tinggi

b. Penentuan Indikator pembelajaran dan indicator berpikir tingkat tinggi yang akan digunakan untuk mengembangkan instrument kemampuan berpikir kritis peserta didik.

c. Penyusunan indkator soal dan penulisan soal kemampuan berpikir tingkat tinggi.

d. Penentuan kunci jawaban untuk tes pilihan ganda dan rubrik penialain untuk tes uraian.

2. Metode Tanya jawab, digunakan untuk memberikan peluang kepada peserta bertanya tentang konsep atau prosedur pengembangan instrument kemampuan berpikir tingkat tinggi yang belum dipahami. Pertanyaan-pertanyaan yang diajukan kemudian direspon oleh anggota tim PPM melalui moderator yang mengatur kegiatan di kelas.

3. Metode diskusi, memberikan kesempatan kepada peserta untuk memperdalam pemahamannya tentang instrument kemampuan berpikir berpikir tingkat tinggi dan prosedur analisis Kompetensi Dasar menjadi sejumlah indicator pembelajaran yang berpotensi dikembangkan menjadi soal kemampan berpikir tingkat tinggi.

4. Metode Contoh non contoh, digunakan untuk menunjukkan kepada peserta pengabdian tentang contoh-contoh instrument kemampuan berpikir tingkat tinggi melalui pembelajaran IPA SMP. Dalam hal ini telah ditunjukkan kepada peserta photo copy tes kemampuan berpikir kritis sebagai salah satu instrument kemampuan berpikir tingkat tinggi..

5. Penugasan, digunakan untuk menugaskan kepada peserta untuk berlatih mengembangkan instrument kemampuan berpikir tingkat tinggi melalaui pembelajaran IPA SMP sesuai dengan contoh dan prosedur yang ditunjukkan oleh tim PPM. Hasil latihan tersebut kemudian dikumpulkan kepada tim PPM.

\section{Hasil dan Pembahasan}

Kegiatan pengabdian pada masyarakat dengan judul "Pelatihan Penyusunan Instrumen Keterampilan Berpikir Tingkat Tinggi Bagi Pendidik Mata Pelajaran IPA SMP di Kota
Mataram", telah terlaksana sesuai dengan rencana. Peserta kegiatan pengabdian ini diikuti oleh pendidik-pendidik IPA SMP yang tergabung dalam MGMP IPA Kota MAtaram. Selama kegiatan pengabdian peserta mengikutinya dengan semangat, karena materi kegiatan pengabdian yang disampaikan oleh tim sangat relevan dengan kebutuhan dan tugas mereka sebagai pendidik IPA SMP. Hal itu disebabkan mereka belum memahami dengan tentang konsep dan prosedur pembangan instrument kemampuan berpikir tangkat tinggi. Mereka mengakui bahwa materi yang diperolehpada kegiatan PPM tersebut sangat penting untuk dikuasai sesuai dengan tuntutan penerapan Kurikulum 2013 yang diberlakukan secara Nasional.

Alat evaluasi atau instrument penialian hasil belajar yang disusun oleh pendidik IPA selama ini adalah instrument evaluasi yang berorientasi hanya pada penguasaan konsep atau materi pelajaran. Penyusunan instrumen kemampuan berpikir tingkat tinggi peserta didik belum pernah mereka lakukan secara terencana sesuai dengan konsep dan prosedur pengembangan soal-soal HOTs. Hal tersebut karena mereka belum pernah mengikuti kegiatan pelatihan yang khusus tentang pemberdayaan berpikir tingkat tinggi peserta didik melalui pembelajaran IPA SMP. Untuk itu dengan telah terlaksananya kegiatan PPM ini merupakan hal yang sangat bermanfaat bagi pendidik IPA di Kota Mataram. Kegiatan PPM ini sangat sesuai dengan kebijakan Kemendikbut dalam penerapan kurikulm 2013 diantaranya mengembangkan kemampuan berpikir tingkat tinggi peserta didik melalui pembelajaran IPA SMP.

Keterlaksanaan kegiatan pengabdian pada masyarakat tentang "Pelatihan Penyusunan Instrumen Keterampilan Berpikir Tingkat Tinggi Bagi Pendidik Mata Pelajaran IPA SMP di Kota Mataram" telah memberikan kontribusi yang amat berharga bagi pendidik IPA SMP yang tergabung dalam MGMP IPA. Para pendidik tersebut telah memperoleh beberapa manfaat diantaranya:

1. Memperluas wawasan mereka tentang konsep dan prosedur pengembanga instrumen kemampuan berpikir tingkat tinggi peserta didik melalui pembelajaran IPA di SMP

2. Para pendidik IPA lebih memahami konsep dan prosedur penyusunan instrument atau tes kemampuan berpikir tingkat tinggi peserta didik. Pemahaman tersebut amat penting dalam 
upaya mempersiapkan generasi emas Indonesia yang diharapkan tercapai pada tahun 2045 .

3. Para pendidik IPA telah memiliki keterampilan dalam merancang sitem evaluasi yang berorientasi pada pengembangan kemampuan berpikir tingkat tinggi peserta didik. Hal ini sangat penting untuk mengembangkan kemampuan berpikir tingkat tinggi peserta yang sangat dibutuh untuk melahirkan SDM Indonesia masa depan agar mampu bersaing dengan SDM dari Negara lain dalam era persaingan global dalam semua sector berkehidupan bernegara.

Faktor pendukung pada kegiatan pengadian ini diantaranya adalah lokasi kegiatan di SMP 10 Mataram yang digunakan sebagai lokasi kegiatan MGMP. Para pendidik yang mengikuti kegiatan pengabdian ini dapat dengan mudah mencapai lokasi tersebut. Materi kegiatan PPM yang disampaikan adalah materi yang sangat mendukung kompetensi paedagogik pendidik. Dengan demikian materi tersebut merupakan hal yang menjadi kebutuhan oleh pendidik IPA yang terlibat dalam kegiatan pengabdian ini. Materi kegiatan ini merupakan salah satu materi pokok dari kegiatan MGMP. Dengan adanya faktor-faktor pendukung tersebut maka kegiatan pengabdian ini dapat berjalan dan mancapai hasil sesuai dengan tujuan kegiatan pengebdian pada masyarakat ini.

Hambatan-hambatan yang ditemukan dalam pelaksanaan kegiatan pengabdian pada masyarakat ini diantaranya adalah minimnya sumber belajar yang berkaitan dengan upaya pengembangan instrument kemampuan berfikir tingkat tinggi peserta didik. Sumber belajar dimaksud diantanya adalah buku-buku tentang konsep dan prosedur atau contoh pengembangan instrument kemampuan berpikir tingkat tinggi peserta didik. Hal ini telah menyebabkan kesulitan bagi pendidik dalam menyusun instrumen yang berpotensi mengembangkan kemampuan berpikir tingkat tinggi peserta didik secara terencana. Untuk mengatasi hambatan ini tim pengabdian membantu peserta untuk memperoleh bahan sebagai acuan untuk mengembangkan instrument kemampuan berpikir tingkat tinggi dalam bentuk foto copyan. Faktor penghambat berikutnya adalah kurang terlatihnya pendidik dalam merumuskan indicator pencapaian kompetensi yang berorientasi pada pengembangan berpikir tingkat tinggi.

\section{Kesimpulan}

Kegiatan pengabdian pada masyarakat tentang "Pelatihan Penyusunan Instrumen Keterampilan Berpikir Tingkat Tinggi Bagi Pendidik Mata Pelajaran IPA SMP di Kota Mataram" telah dapat terlaksana sesuai dengan tujuan kegiatan. Kegiatan tersebut dinilai sangat bermanfaat bagi pendidik-pendidik IPA yang menjadi peserta dalam kegiatan PPM. Melalui kegiatan dimaksud para peserta telah memiliki wawasan tentang konsep dan prosedur penyusunan instrument kmampuan berpikir tingkat tinggi peserta didik melalui pembelajaran IPA.

Dari hasil kegiatan pengebdian pada masyarakat ini diharapkan dapat memberikan kontribusi yang posistif bagi pengembangan kompetensi paedagogir pendidik IPA di Kota Mataram. Peningkatan kompetensi pendidik IPA khususnya dalam menyusun system evaluasi yang secara sengaja dan terencana untuk mengembangkan kemampuan berpikir tingkat tinggi peserta didik. Dengan demikian diharapkan peserta didik dapat mengembangkan kemampuan berpikir tingkat tinggi peserta didik melalui pembelajaran IPA SMP.

\section{Saran}

Kepada para pendidik IPA yang terlibat sebagai peserta kegiatan pengabdian disarankan:

1. Pendidik IPA memiliki komitmen untuk berupaya mengembangkan kemampuan berpikir tingkat tinggi peserta didik melalui pembelajaran IPA di SMP.

2. Pedidik IPA diharapkan berlatih secara terus menerus dalam mengembangkan dan menerapkan system evaluasi yang dapat melatih siswa dalam berikir tingkat tinggi. Kemampuan berpikir tingkat tinggi diantaranya kemampuan berpikir kritis, Berpikir kreatif, dan beroikir memberikan argument.

3. Pendidik IPA telah mampu mmengembangkan instrumn kemampuan berpikir tingkat tinggi agar bersedia berbagi untuk teman pendidik IPA yang lainnya. Dengan cara ini dapat diharapkan para pendidik IPA lainnya dapat memahami dan memiliki kemampuan dalam mengembangkan instrument evaluasi yang 
mampu meningkatkan kemampuan berpikir tingkat tinggi peserta didik.

\section{Daftar Pustaka}

Corebima, A.D. \& Al Idrus, A. 2006. Pengembangan dan Pengukuran Kemampuan Berpikir pada Pembelajaran $I P A$. Proceeding of the 3rd Internasional Conference on Measurement and Evaluation in Education (ICMEE 2006), School of Educational Studies Universiti Sains Malaysia, Penang, 13-15 Pebruary.

Ennis, R. 1985. Goals for Critical Thingking Curriculum. In A.L. Costa, Developing Minds: A Resource Book for Teaching Thinking. Alexandria: Association for Supervisor and Curriculum Development (ASCD).

De Bono, E. 2007. Revolusi Berpikir. Terjemahan Oleh Ida Sitompul dan Fahmi Yamani. Bandung: Kaifa.

Handoko, 2007. Pengaruh Pembelajaran Inkuiri dan Strategi Kooperatif Terhadap Hasil Belajar Kognitif, Kemampuan Berpikir Kritis, dan Kemampuan Kerjasama Siswa SMA Berkemampuan Atas dan Bawah Di Kota Metro Lampung.Disertasi. Tidak Diterbitkan. Malang: Program Pasca Sarjana Universitas Negeri Malang.

Hassoubah, Z.I. 2002. Mengasah Pikiran Kreatif dan Kritis. Terjemahan oleh Bambang Suryadi, 2007. Bandung: NUANSA.

Kemndikbud, 2017. Modul Penyusunan Soal Higher Order Thinking Skills (HOTS). Jakarta: Direktorat Pembinaan SMA Ditjen Pendidikan Dasar dan Menengah.

Langreh, J., 2006. Thiking Skill. Mengajarkan Kemampuan Berpikir pada Anak. Jakarta: PT Elex Media Komputindo.

Nurmalia, C. 2009. Kemampuan Berpikir Kritis, Metakognisi dan hasil Belajar IPA Siswa SMP Negeri di Kota Malang. Disertasi, tidak diterbitkan. Malang: Program Pascasarjana Universitas Negeri Malang.

Pratiwi, T.R, \& Muslim, 2016. Pembelajaran IPATipe Integrated Untuk Meningkatkan kemampuan Berpikir Kritis Siswa SMP. Jurnal Pendidikan Fisika Indonesia 12 (1) 54-64
Primarindah, I., Prayitno, B.A., \& Maridi, 2014. Pengembangan Modul Berorientasi Problem Based Learning (PBL) Pada Materi Pencemaran Utuk Memberdayakan Kemampuan Berpikir Kritis dan Sikap Peduli Lingkungan Siswa SMA Negeri 1 Karanganyar. Prosiding Seminar Nasional Pendidikan Sains IV, Program Studi Magister Pendidikan Sains Program Pascasarjana FKIP Universitas Sebelas Maret, Surakarta 15 November 2014.

Reid, J.C. 2006. Mengajari Anak Berpikir Kreatif, Mandiri, Mental, dan Analitis. Terjemahan oleh Ahada Eriawan. 2006. Jakarta: Prestasi Pustakarya.

Sarwi \& Liliasari 2009. Penerapan Strategi Kooperatif Dan Pemecahan Masalah Pada Konsep Gelombang Untuk Mengembangkan Kemampuan Berfikir Kritis. Jurnal Pendidikan Fisika Indonesia: 5(2009). 9095.

Susilawati, 2017. Pengaruh Model Pembelajaran Berbasis Masalah (PBM) Berbantuan Multimedia Terhadap Literasi Sains Dan Kemampuan Berpikir Kritis Peserta Didik Kelas VII SMP Negeri 2 Mataram Ditinjau Dari kemampuan Akademik. Tesis: Pascasarjana Universitas Mataram

Tawil, M., \& Liliasari. 2013. Berpikir Kompleks dan Implementasinya dalam Pembelajaran IPA. Makassar: Badan Penerbit UNM.

Wahyuni, S., 2015. Pengembangan Perangkat Pembelajaran IPA Berbasis Kearifan Lokal Untuk Meningkatkan Kemampuan Berpikir Kritis Siswa. Jurnal Pendidikan Fisika Indonesia 11 (2) (2015) 156-161 